\title{
Partitioning of trophic resource on example of the rodent community dwelling in the high mountain zone of the Eastern Caucasus
}

\author{
Magomedrasul Magomedov* \\ Caspian Institute of Biological Resources RAS, 368025, Makhachkala, Russia
}

\begin{abstract}
Quantitative and qualitative feeding characteristics of some rodent species co-living in the high mountain zone of the Eastern Caucasus (Republic of Daghestan) were investigated. The diet of $S$. uralensis consisted of 23 plant species, C. gud -22 plant species, M. arvalis -27 plant species, $C$. migtatorius -26 plant species and $D$. nitedula -19 plant species. The largest dietary breadths were $M$. arvalis and C. migtatorius and the least was S. uralensis. In spring, Carex spp. predominated in the diets of rodent species; in summer, the diets consisted mainly of cereals, and the autumn rodents diets consisted mainly of forbs and legumes. The maximum values of the dietary niches overlapping were found in pairs of the following species: S. uralensis C. gud, C. gud - C. migtatorius, M. arvalis - C. migtatorius. Average values of the dietary niches overlapping for all rodents were $0.529,0.277,0.459$, respectively, in spring, summer and autumn.
\end{abstract}

\section{Introduction}

The coexistence of similar species within the same ecosystem may occur owing to different resource use. Resource partitioning includes food, habitat and/or time segregation. Revealing of utilization mechanisms of vegetation food between ecologically and taxonomically similar species sheds light on the issues of sustainability and functioning of communities in the modern ecology. Among the many factors that forming a community structure food resource is considered as key one $[1,2,3$, 4, 5].

Resources partition is based on the concept of an ecological niche. According to the niche theory, coexisting species must exhibit ecological differences in at least one niche dimension, such as space, food or time. Therefore, there is a mechanism that allows species to segregate key factors or resources which the food is definitely thought main one; differences in qualitative or quantitative diet composition, consumption in space and time, etc $[5,6]$.

Trophic interactions are key determinants of the structure and dynamics of ecological niches in coexisting species. The dietary niche defines the role of a species in a local food web, identifying energy transfer routes from food resources. The dietary niche is width mostly defined by the selectivity of the species, which contribute in defining the range of food resources. However, species dietary niche is generally characterized by a certain degree of intrinsic plasticity, allowing diet shifts when competition occurs. In wideranging species, it is likely that populations forage in environments differing in terms of resource availability and trophic networks. Therefore, conspecifics of different populations adapt their feeding habits to the local food availability [7].

Mountainous are a good platform for studying the peculiarities of the coexistence of ecologically close species and, in general, ways of forming the structure of communities. The presence of plant, soil, relief and microclimatic differences should contribute to formation of mechanisms that allow species of one trophic link to inhabit a common space.

This paper presents an assessment of the quantitative and qualitative distribution of vegetation resources between the species of the rodent community in the high mountain zone of the Republic of Daghestan. For this purpose, the composition and proportion of the eaten plant species were determined, the diversity of the eaten food was revealed, the degree of similarity of the diets in the rodent species forming the model community was calculated.

\section{Materials and methods}

The studies were carried out in the high mountain zone of the Republic of Daghestan, on the territories of the Mountain Botanical Garden of the Russian Academy of Sciences $\left(41^{\circ} 03\right.$ '- $41^{\circ} 48^{\prime} \mathrm{N}$ and $\left.46^{\circ} 13^{\prime}-46^{\circ} 47^{\prime} \mathrm{E}\right)$ and the Federal Reserve "Tlyaratinsky" $\left(41^{\circ} 03\right.$ '- $41^{\circ} 48^{\prime} \mathrm{N}$ and $46^{\circ} 13$ '- $46^{\circ} 47^{\prime}$ E). Field material was collected in spring (May), summer (July) and autumn (October) 2017 - 2020 years, model areas are located in the range of altitudes from 1600 to $2200 \mathrm{~m}$ a.s.l.

Climate of the mountainous part of Daghestan is sharply continental with cold winters and cool summers.

\footnotetext{
*Corresponding author: mmsh78@mail.ru
} 
The average winter temperature is $-7^{\circ} \mathrm{C}$, the average summer temperature is $+16^{\circ} \mathrm{C}$. Precipitation is unevenly distributed depending on the geographic location and the ruggedness degree of the territory [8].

The work was carried out in the forest and subalpine belts of the high mountain zone. Forests are located mainly on the northern and eastern slopes and represented by Pinus kochiana Klotzsch, Betula verrucosa, B. pendula Roth., B. litwinowii Doluch., Carpinus betulus L., Quercus macranthe Fisch. \& C.A.Mey. ex Hohen. Shrubs: Juniperum hemisphaerica J. et C. Presl., Rosa kamelinii Gussejnov, Rhododendron caucasicum Pall., Ribes biebersteinii Berl., Vaccinium myrtillus L. On the southern slopes are located mountain steppes with grasses and herbs prevail [9]. In spring, plant associations are represented by ephemerals and ephemeroids. In late spring and summer grasses and forbs occupy a dominant position; in autumn grasses significantly reduce their presence in the phytocenosis. Hence, the index of species diversity of herbaceous vegetation was maximum in summer, then in autumn and minimum in spring. Of the herbaceous vegetation 97 species were identified in the study area, the most typical of which; Carex tristis Bieb., Calamagrostis caucasica Trin., Dactylis glomerata L., Elymus repens Gould., Scilla siberica Haw., Agrostis lazica Bal., Alchimila caucasica Bus., Betonica grandiflora K. Koch., Galium odoratine L., Veronica alpine and etc [9].

Vegetation description was carried out by standard methods of field botany [10]. Herbaceous projective cover level on open areas were $69.3 \pm 3.7 \%(n=24)$, in forest $-8.7 \pm 0.02 \%$. Herbaceous aboveground phytomass were: $6.1 \pm 0.03$ centner dried mass on 1 ha in May $(n=$ 43), $3.74 \pm 0.05$ centner dried mass on 1 ha $(n=35)$ in July and $3.35 \pm 0.02$ centner dried mass on 1 ha in September $(n=34)$. Trees density is $261 \pm 19$ ind./0.125 ha, shrubs density is $687 \pm 72$ ind./0.125 ha $(n=8)$.

\subsection{Species}

Five species were included in the study: Sylvaemus uralensis Pallas $1811 \quad(21.9 \pm 1.21 \mathrm{~g}), \quad$ Cricetulus migratorius Pallas 1773 (20.5 $\pm 1.11 \mathrm{~g})$, Microtus arvalis Pallas 1778 (39.4 \pm 2.0 g), Dryomys nitedula Pallas 1779

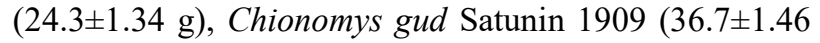
g). Abundance of model species are: S. uralensis $15.4 \pm$ 0.67 ind./100 traps nights, $M$. arvalis $9.57 \pm 0.62$ ind./100 traps nights, $C$. gud $6.75 \pm 0.86$ ind./100 traps nights, C. migratorius $4.16 \pm 0.33$ ind./100 traps nights, D. nitedula $4.03 \pm 0.45$ ind./100 traps nights.

\subsection{Dietary analysis}

Simultaneously with vegetation description model rodent species excrement were collected for diet analysis at the same time and places. The diets of rodent species were assessed by the identification of food items in faecal samples collected from animals captured in the study areas. A microhistological analysis was carried out by comparing the plant fragments in the samples to a reference collection of the most common local plant species (stem, leaf, seed and flower). Over 118 species of food plants that occur in the study areas were sampled for the reference slides. The samples were collected and dried to avoid further decomposition and then cleared of pigments for slide plating using a maceration process in $\mathrm{HNO}_{3}$ to oxidize all the organic material. The ingested plant materials in the faeces were compared to epidermal fragments on the reference slides. Three slides were prepared for each of the faecal samples collected. Only fragments that had at least two diagnostic characteristics (morphology of cells, stomas, epidermal hairs) were considered as evidence of species presence. Only fragments larger than $0.01 \mathrm{~mm}^{2}$ were considered, as smaller fragments often do not have enough features for accurate identification to the species level. Identification of the epidermal materials was carried out to the species level. The samples were analysed using a microscope (MICROMED 1, version 3-20) under 40× magnification; over 1940 epidermis fragments were processed in a sample. The taxon percentage was calculated as the ratio of the number of fragments of a particular taxon to the total number of fragments in a sample [4].

\subsection{Frequency of occurrence (FO)}

For the FO, the percentage of a plant species was recorded in each faecal sample, and the results are expressed as the percentage of the sample that contained the food item in relation to the total number of samples, that is

$$
\mathrm{FO}(\%)=100 n / N \text {, }
$$

where FO (\%) is the relative frequency of occurrence of a food item, $n$ is the number of samples in which a food item occurred, and $N$ is the total number of faeces samples analyzed.

The niche breadth was estimated using Levin's index (B) and Levin's standardized niche breadth ( $\left.\mathrm{B}_{\text {stand. }}\right)$ [11]:

$$
\mathrm{B}=1 / \Sigma \mathrm{pi}^{2},
$$

where $p$ is the relative proportion of records for each resource $i$ used by a species.

$$
\mathrm{B}_{\text {stand. }}=(\mathrm{B}-1) /(\mathrm{n}-1),
$$

where $n$ is the number of possible food categories.

Niche overlap was calculated with the index of Pianka (1973) [12];

$$
\mathrm{O}_{\mathrm{ij}}=\mathrm{O}_{\mathrm{ik}}=\left(\Sigma \mathrm{p}_{\mathrm{ij}} \mathrm{p}_{\mathrm{ik}}\right) /\left(\sqrt{ } \Sigma \mathrm{p}_{\mathrm{ij}}^{2} \Sigma \mathrm{p}_{\mathrm{ik}}^{2}\right),
$$

where $p_{i j}$ and $p_{i k}$ are the relative frequency of occurrence of resource $i$ for species $j$ and k. Pianka's index varies from 0 (total separation of resource use) to 1 (complete overlap in resource use).

The overlap values in the range of 0 to 0.25 were considered low, from 0.25 to 0.5 were considered moderate, from 0.5 to 0.75 were considered high and from 0.75 and up were considered very high. 


\section{Results}

Totally 54 plant species were identified in the diets of the model rodent community species. The diet of $S$. uralensis consisted of 23 plant species, C. gud - 22 plant species, M. arvalis - 27 plant species, C. migtatorius 26 plant species and $D$. nitedula -19 plant species. The largest dietary breadths were $M$. arvalis and $C$. migtatorius and the least was S. uralensis (Table 1). In all rodents' diets were revealed a prevalence of certain vegetation groups seasonally. In spring, rodents consumed ephemeras and cereals, summer - cereals and forbs and in autumn - forbs. The consumption of rodents coincide with the natural development the phases of the phenological cycle of the herbaceous plants. Diversity of forages in the rodents diets were maximum in summer, then in autumn and the minimum value was in the spring (Table 1). Share of plants in the rodents diets, except $D$. nitedula, correlated with plants shares in the phytocenosis $(\mathrm{p} \leq 0.05)$.

Dominance of Carex spp. in the rodent diets in spring is explained by their dominant position in the phytocenosis $(59.2 \%)$. Gramineae family could not be determined a species status because the earing phase did not begin in the spring. That is why all cereal species were combined into a one group in Table 1. Moreover the share of cereals in the diets of rodents was no more than $7 \%$. In summer, the diet of rodents consisted mainly of cereals, whose share in the phytocenosis was $68 \%$. In autumn, most of the cereals (up to 90 percent) completed their natural phenological cycle; only cereals with green stem bases were noted. This period of the year fiber content in cereals reaches maximum value (Magomedov, Yarovenko, 1997). If take into account only the metabolically active parts of cereal plants they still dominate in phytocenosis $(61.8 \pm 3.1 \%)$. At the same time, in the diets of each rodent the share of cereals was $11 \%$. The autumn diet of rodents consisted of species of groups of forbs and legumes (more than 90\%) (Table 1).

The number and percentage of exclusively consumed plants species were also calculated. Share of these plants in the diets of the $S$. uralensis was $4.3 \%, C$. gud $13.6 \%$, M. arvalis $-18.5 \%$, C. migtatorius $-15.4 \%$ and D. nitedula $-21 \%$. So, specialization in a particular plant species in the diets of rodents is poorly expressed. The ratio of monocotyledonous and dicotyledonous plant species in the model rodents diets showed that the monocotyledonous dominated. Only in $D$. nitedula diet the dicotyledonous plants dominated. Among monocotyledonous plant species the share of cereal species was maximal in the diets of rodent species.

Based on the revealed rodents dietary niches dates the degree of overlapping was seasonally calculated (Tables 2, 3, 4). The maximum values of the dietary niches overlapping were found in pairs of the following species: S. uralensis - C. gud, C. gud - C. migtatorius, $M$. arvalis $-C$. migtatorius (Table 2, 3, 4). Average values of the dietary niches overlapping for all rodents were $0.529,0.277,0.459$, respectively, in spring, summer and autumn. In spring, when the phytomass level and plants diversity were minimal the dietary niches overlapping in rodent community was high $(p<0.05)$ and in summer was minimal $(p<0.05)$

\section{Discussion}

Species composition and the share of vegetation food consumed by the model rodent species dwelling in the high mountain zone of the Republic of Daghestan were revealed. The diets of the rodents were characterized by wide composition (from 19 to 27 plant species), the animals showed a high feeding behavior pattern; changing one forage plant species or group to another that indicates their typical polyphagia. The share of exclusively consumed plants species did not exceed $21 \%$ in the diets of the considered rodents.

All rodents, except $D$. nitedula, showed association of diet composition with the vegetation structure. $D$. nitedula lifestyle is little different from the rest species of rodents community. Firstly, it is an arboreal-terrestrial life-style which as result the presence of arboreal and shrub species in the diet of the species and secondly, the $D$. nitedula consumes animal food too. That is why the minimum values dietary niche overlapping between $D$. nitedula and other rodents were revealed. Generally degree dietary niche overlapping in the rodent community was characterized in a wide range; in 12 of 30 pairs of rodents (data for three seasons) were shown a high and a very high.

A general, dietary overlap between species was described by many authors. The degree of dietary overlap may change during the year and reach a maximum when food availability is at a low level. Authors emphasized the importance of dietary resources in competition among rodents and Gliwicz (1981) inferred from experimental data that the ultimate resource in competition is food.

The main question is how can species with the high degree of dietary overlapping coexist in the common space? In many papers were shown a coexistence pattern of species characterized by a high degree of dietary overlapping under conditions of sufficient food supply $[12,13,14,15,16,17]$.

Moreover, the structural niche of a species consists of, besides the trophic component, spatial and temporal components, division over which can significantly facilitate coexistence of species in a common space.

Discussing species coexistence by dietary niche it is more important to take into account the level of food supply (phytomass) then the degree of similarity of diets. A requirement of an organism must correspond to the possibilities of obtaining food in an environment. Realization of this condition depends on resources volume, ability to obtain and use them effectively [18].

For the coexistence of co-living species is important the lower level of food supplies. In the study area the level of the ground herbaceous vegetation mass corresponded to the long-term average value seasonally in 2017-2020 years. 
Table 1. Frequency of occurrence of identified food items in the diets of the model rodent species and dietary breadth in study area

\begin{tabular}{|c|c|c|c|c|c|c|}
\hline \multirow{2}{*}{ Rodents } & \multicolumn{6}{|c|}{ Food items } \\
\hline & Spring & $\%$ & Summer & $\%$ & Autumn & $\%$ \\
\hline \multirow[t]{2}{*}{ S. uralensis } & $\begin{array}{l}\text { Festuca pratensis } \\
\text { Carex tristis } \\
\text { Poa bulbosa } \\
\text { Veronica alpina } \\
\text { Scilla siberica } \\
\text { Gallium spp. } \\
\text { Trifolium pratense } \\
\text { Alchemilla caucasica } \\
\text { Vicia cracca } \\
\text { Inula orientalis } \\
\text { Gramineae } \\
\text { Undetermined }\end{array}$ & $\begin{array}{l}33.7 \\
17.5 \\
11.3 \\
7.4 \\
5.9 \\
3.7 \\
3.18 \\
2.41 \\
1.86 \\
1.75 \\
6.43 \\
4.87\end{array}$ & $\begin{array}{l}\text { Phleum pratence } \\
\text { Elytrigia repens } \\
\text { Calamagrostis caucasica } \\
\text { Festuca pratensis } \\
\text { Astragalus biebersteinii } \\
\text { Trifolium pratense } \\
\text { Gallium spp. } \\
\text { Seseli libanotis } \\
\text { Vicia cracca } \\
\text { Capsella bursa-pastoris } \\
\text { Alchemilla caucasica } \\
\text { Ranunculus caucasicus } \\
\text { Undetermined }\end{array}$ & $\begin{array}{l}15.3 \\
13.4 \\
12.5 \\
10.7 \\
9.3 \\
7.6 \\
5.7 \\
5.8 \\
4.6 \\
3.7 \\
2.5 \\
1.2 \\
7.3\end{array}$ & $\begin{array}{l}\text { Geranium sylvaticum } \\
\text { Alchemilla caucasica } \\
\text { Trifolium pratense } \\
\text { Andreaea spp. } \\
\text { Thymus serpyllum } \\
\text { Gallium spp. } \\
\text { Spiraca hypericifolia } \\
\text { Sedum oppositifolium } \\
\text { Calamagrostis caucasica } \\
\text { Capsella bursa-pastoris } \\
\text { Undetermined }\end{array}$ & $\begin{array}{l}22.4 \\
17.1 \\
13.6 \\
11.3 \\
8.2 \\
7.4 \\
6.7 \\
4.4 \\
3.4 \\
1.6 \\
3.7\end{array}$ \\
\hline & \multicolumn{2}{|c|}{$\mathrm{D} / \mathrm{D}_{\text {stand. }}=5.68 / 0.47(\mathrm{n}=23)$} & \multicolumn{2}{|c|}{$\mathrm{D} / \mathrm{D}_{\text {stand. }}=7.35 / 0.56(\mathrm{n}=26)$} & \multicolumn{2}{|c|}{$\mathrm{D} / \mathrm{D}_{\text {stand. }}=7.57 / 0.69(\mathrm{n}=19)$} \\
\hline \multirow[t]{2}{*}{ C. gud } & $\begin{array}{l}\text { Festuca pratensis } \\
\text { Poa bulbosa } \\
\text { Gallium spp. } \\
\text { Veronica alpina } \\
\text { Alchemilla caucasica } \\
\text { Cerastium multiflorum } \\
\text { Gramíneae } \\
\text { Ornithogalum balansae } \\
\text { Trifolium pratense } \\
\text { Scilla siberica } \\
\text { Undetermined }\end{array}$ & $\begin{array}{l}29.7 \\
24.4 \\
18.7 \\
14.1 \\
9.4 \\
8.5 \\
7.6 \\
4.4 \\
4.3 \\
3.7 \\
2.8\end{array}$ & $\begin{array}{l}\text { Festuca pratensis } \\
\text { Alchemilla caucasica } \\
\text { Elytrigia repens } \\
\text { Calamagrostis caucasica } \\
\text { Agrostis lazica } \\
\text { Gallium spp. } \\
\text { Betonica grandiflora } \\
\text { Ranunculus caucasicus } \\
\text { Capsella bursa-pastoris } \\
\text { Thymus serpyllum } \\
\text { Pastinaca armena }\end{array}$ & $\begin{array}{l}19.5 \\
16.9 \\
14.5 \\
10.7 \\
9.8 \\
9.2 \\
8.2 \\
4.1 \\
3.4 \\
2.2 \\
1.4\end{array}$ & $\begin{array}{l}\text { Alchemilla caucasica } \\
\text { Andreaea spp. } \\
\text { Betonica grandiflora } \\
\text { Lathyrus cyaneus } \\
\text { Trifolium pratense } \\
\text { Spiraca hypericifolia } \\
\text { Calamagrostis caucasica } \\
\text { Thymus serpyllum } \\
\text { Vaccinium myrtillus } \\
\text { Gallium spp. } \\
\text { Elytrigia repens } \\
\text { Undetermined }\end{array}$ & $\begin{array}{l}22.1 \\
16.1 \\
13.2 \\
10.6 \\
9.4 \\
7.7 \\
4.6 \\
4.1 \\
2.6 \\
2.4 \\
3.5 \\
3.7\end{array}$ \\
\hline & \multicolumn{2}{|c|}{$\mathrm{D} / \mathrm{D}_{\text {stand. }}=4.34 / 0.39(\mathrm{n}=12)$} & \multicolumn{2}{|l|}{$\mathrm{D} / \mathrm{D}_{\text {stand. }}=7.85 / 0.71(\mathrm{n}=14)$} & \multicolumn{2}{|c|}{$\mathrm{D} / \mathrm{D}_{\text {stand }}=7.95 / 0.66(\mathrm{n}=17)$} \\
\hline \multirow[t]{2}{*}{ M. arvalis } & $\begin{array}{l}\text { Poa bulbosa } \\
\text { Festuca pratensis } \\
\text { Gallium spp. } \\
\text { Convolvulus arvensis } \\
\text { Ranunculus caucasicus } \\
\text { Primula algida } \\
\text { Vicia cracca } \\
\text { Astrantia biebersteinii } \\
\text { Ornithogalum balansae } \\
\text { Potentilla multifida } \\
\text { Trifolium pratense } \\
\text { Gramineae } \\
\text { Undetermined }\end{array}$ & $\begin{array}{l}15.2 \\
13.3 \\
12.1 \\
10.5 \\
9.5 \\
8.5 \\
7.7 \\
6.6 \\
4.6 \\
2.7 \\
1.1 \\
6.7 \\
1.5\end{array}$ & $\begin{array}{l}\text { Calamagrostis caucasica } \\
\text { Betonica grandiflora } \\
\text { Briza media } \\
\text { Phleum pratence } \\
\text { Dactylis glomerata } \\
\text { Elytrigia repens } \\
\text { Gallium spp. } \\
\text { Trifolium pratense } \\
\text { Linum nervosum } \\
\text { Achillea millefolium } \\
\text { Thymus serpyllum } \\
\text { Vicia cracca } \\
\text { Salvia beckeri } \\
\text { Bupleurum longiradiatum } \\
\text { Undetermined }\end{array}$ & $\begin{array}{l}16.5 \\
13.7 \\
11.0 \\
10.1 \\
9.6 \\
9.1 \\
8.3 \\
5.8 \\
4.4 \\
2.5 \\
2.3 \\
2.1 \\
1.8 \\
1.2 \\
1.6 \\
\end{array}$ & $\begin{array}{l}\text { Andreaea spp. } \\
\text { Geranium sylvaticum } \\
\text { Betonica grandiflora } \\
\text { Trifolium pratense } \\
\text { Alchemilla caucasica } \\
\text { Thymus serpyllum } \\
\text { Hordeum violaceum } \\
\text { Sedum oppositifolium } \\
\text { Dactylis glomerata } \\
\text { Calamagrostis caucasica } \\
\text { Undetermined }\end{array}$ & $\begin{array}{l}18.5 \\
15.3 \\
14.1 \\
12.7 \\
9.8 \\
8.3 \\
6.5 \\
5.2 \\
2.7 \\
1.3 \\
5.5\end{array}$ \\
\hline & \multicolumn{2}{|c|}{$\mathrm{D} / \mathrm{D}_{\text {stand. }}=9.93 / 0.76(\mathrm{n}=12)$} & \multicolumn{2}{|c|}{$\mathrm{D} / \mathrm{D}_{\text {stand. }}=9.97 / 0.66(\mathrm{n}=18)$} & \multicolumn{2}{|c|}{$\mathrm{D} / \mathrm{D}_{\text {stand. }}=7.96 / 0.72(\mathrm{n}=16)$} \\
\hline \multirow[t]{2}{*}{ D. nitedula } & $\begin{array}{l}\text { Quercus petraea } \\
\text { Poa bulbosa } \\
\text { Rubus saxatilis } \\
\text { Trifolium pratense } \\
\text { Betula raddeana } \\
\text { Vicia cracca } \\
\text { Gallium spp. } \\
\text { Inula orientalis } \\
\text { Gramineae } \\
\text { Achillea ptarmicifolia } \\
\text { Undetermined }\end{array}$ & $\begin{array}{l}31.5 \\
18.6 \\
11.9 \\
9.2 \\
7.5 \\
4.3 \\
4.1 \\
3.5 \\
2.2 \\
2.0 \\
5.2\end{array}$ & $\begin{array}{l}\text { Rosa spp. } \\
\text { Spiraca hypericifolia } \\
\text { Phleum pratence } \\
\text { Quercus petraea } \\
\text { Dactylis glomerata } \\
\text { Astragalus biebersteinii } \\
\text { Trifolium pretense } \\
\text { Rubus idaeus } \\
\text { Vícia cracca } \\
\text { Gallium spp. } \\
\text { Achillea ptarmicifolia } \\
\text { Undetermined }\end{array}$ & $\begin{array}{l}21 \\
17 \\
14.3 \\
13.2 \\
11.2 \\
5.7 \\
4 \\
3.4 \\
2.2 \\
1.7 \\
3.8 \\
2.4\end{array}$ & $\begin{array}{l}\text { Rosa spp. } \\
\text { Quercus petraea } \\
\text { Lathyrus cyaneus } \\
\text { Geranium sylvaticum } \\
\text { Betula raddeana } \\
\text { Vicia cracca } \\
\text { Briza media } \\
\text { Rubus idaeus } \\
\text { Betonica grandiflora } \\
\text { Undetermined }\end{array}$ & $\begin{array}{l}20.1 \\
17.2 \\
15.1 \\
9.5 \\
9.1 \\
8.6 \\
7.4 \\
4.5 \\
2.4 \\
6.1\end{array}$ \\
\hline & \multicolumn{2}{|c|}{$\mathrm{D} / \mathrm{D}_{\text {stand. }}=4.85 / 0.44(\mathrm{n}=9)$} & \multicolumn{2}{|l|}{$\mathrm{D} / \mathrm{D}_{\text {stand. }}=7.56 / 0.63(\mathrm{n}=8)$} & \multicolumn{2}{|c|}{$\mathrm{D} / \mathrm{D}_{\text {stand. }}=7.73 / 0.77(\mathrm{n}=11)$} \\
\hline
\end{tabular}




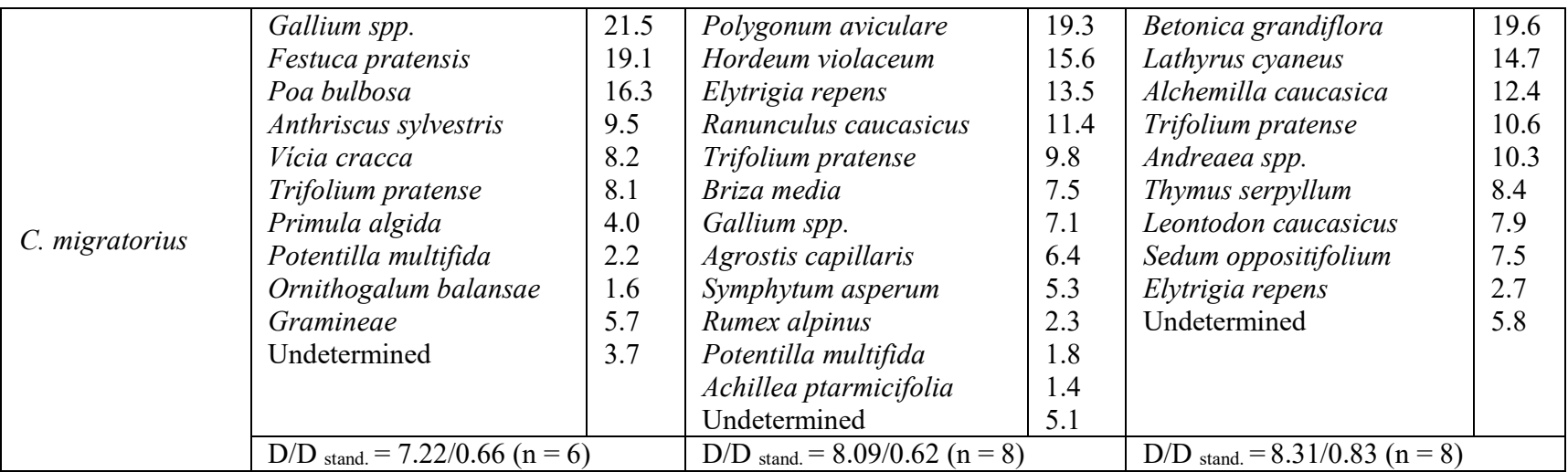

$\mathrm{D}_{\text {stand. }}-$ standardized food breadth index, $\mathrm{n}-$ number of stomachs.

Table 2. Dietary overlap between the model rodent species in spring in the study area

\begin{tabular}{|l|c|c|c|c|c|}
\hline \multicolumn{1}{|c|}{ Species } & S. s. & C. g. & M. a. & C. $m$. & D. $n$. \\
\hline S. uralensis & - & 0.77 & 0.55 & 0.64 & 0.17 \\
\hline C. gud & & - & 0.69 & 0.82 & 0.29 \\
\hline M. arvalis & & & - & 0.75 & 0.28 \\
\hline C. migratorius & & & & - & 0.32 \\
\hline D. nitedula & & & & & - \\
\hline
\end{tabular}

Table 3. Dietary overlap between the model rodent species in summer in the study area

\begin{tabular}{|l|c|c|c|c|c|}
\hline \multicolumn{1}{|c|}{ Species } & S. $s$. & C. $g$. & M. $a$. & C. $m$. & D. $n$. \\
\hline S. uralensis & - & 0.5 & 0.47 & 0.14 & 0.29 \\
\hline C. gud & & - & 0.39 & 0.37 & 0.012 \\
\hline M. arvalis & & & - & 0.3 & 0.25 \\
\hline C. migratorius & & & & - & 0.05 \\
\hline D. nitedula & & & & & - \\
\hline
\end{tabular}

Table 4. Dietary overlap between the model rodent species in autumn in the study area

\begin{tabular}{|l|c|c|c|c|c|}
\hline \multicolumn{1}{|c|}{ Species } & S. $s$. & C. $g$. & M. $a$. & C. $m$. & D. $n$. \\
\hline S. uralensis & - & 0.63 & 0.64 & 0.46 & 0.16 \\
\hline C. gud & & - & 0.68 & 0.83 & 0.17 \\
\hline M. arvalis & & & - & 0.64 & 0.17 \\
\hline C. migratorius & & & & - & 0.21 \\
\hline D. nitedula & & & & & - \\
\hline
\end{tabular}

In conditions of a sufficient food supply and a wide diet composition of rodents the high dietary overlapping cannot be the cause of strengthening of interspecific relations between the studied rodents species. Present community structure is evolutionarily determining construction done in the past [19].

Current species composition in a certain space is explained by the habitation conditions which suitable for all species of a community [20]. The mosaic nature of mountainous area determined a distribution of model rodents among microstations; sufficient level of food supply and intrapopulation mechanisms of adaptation allows coexisting the model rodents in the study area.

\section{References}

1. B.D. Abaturov, Mammals as a component of ecosystems (Science, Moscow, 1984)

2. I.S. Sheremetyev, S.B. Rosenfeld, I.A. Dmitriev, L. Zhargalsaikhan, S. Enkh-Amgalan, Siberian ecological journal. 5 (2014)

3. M-R.D. Magomedov, Zh. Obshch. Biol. 50, 6 (1989)

4. M.S. Magomedov, Zool. Zh. 96, 5 (2017)

5. S.S. Schwartz, Problems of biogeocenology (Nauka, Moscow, 1973)

6. N.V. Bashenina, Adaptation paths of murine rodents (Nauka, Moscow, 1977)

7. E. Lunghi, F. Cianferoni, F. Ceccolini, M. Veith, R. Manenti, G. Mancinelli, et al., PLoS ONE 13, 10 (2018)

8. B.A. Akaev, Physical Geography of Daghestan (School, Makhachkala, 1996)

9. A.A. Lepekhina, Physical Geography of Daghestan (School, Makhachkala, 1996)

10. A.G. Voronov, Geobotany (Higher school, Moscow, 1973)

11. S.H. Hurlbert, Ecology, 59, 1 (1978)

12. E.R. Pianka, Annu. Rev. Ecol. Syst., 4 (1973)

13. E.R. Pianca, Evolutionary ecology (Mir, Moscow, 1981)

14. E.N. Bukvareva, G.M Aleshenko, Advances in modern biology 132, 4 (2012)

15. A.S. Severtsov, Zh. Obshch. Biol. 73, 5 (2012)

16. S.P. Hubbell, Funct Ecol 19, 1 (2005)

17. J.S. Clark, Trends Ecol. Evol. 24 (2009)

18. K.O. Larionov, Food and food supply for Saiga tatarica saigas, depending on the characteristics of the vegetation on the pastures. (Severtsov Institute of Ecology and Evolution, Moscow, 2008)

19. J.H. Connell, Oikos 35 (1980)

20. D. Lack, Ecological Isolation in Birds (Blackwell Scientific Publ., Oxford, 1971). 